\title{
ANALISIS KEBUTUHAN ANGKUTAN UMUM BUS DI KABUPATEN BANGKA
}

\author{
Feriansyah Ramadhani \\ Jurusan Teknik Sipil, Fakultas Teknik, Universitas Bangka Belitung, Bangka \\ email : feriansyah1994@gmail.com \\ Ormuz Firdaus \\ Staf Pengajar Jurusan Teknik Sipil, Universitas Bangka Belitung, Bangka \\ email: ormuz.firdaus@yahoo.co.id \\ Endang Setyawati Hisyam \\ Email : hisyam.endang@gmail.com
}

\begin{abstract}
ABSTRAK
Peningkatan sarana dan prasarana transportasi di Bangka Belitung yang terus dilakukan, untuk mengimbangi permasalahan transportasi yang terjadi belum memberikan pengaruh yang signifikan bagi permasalahan yang dihadapi. Dominannya pengguna kendaraan pribadi perlu diimbangi dengan pembangunan sarana angkutan berupa angkutan umum bus. Angkutan umum bus merupakan suatu penerapan manajemen lalu lintas dengan meniru carpooling yang mengurangi penggunaan kendaraan pribadi yang digunakan menuju pusat kegiatan dengan satu armada angkutan umum berupa bus. Tujuan dari penelitian ini untuk menganalisis karakteristik sosial ekonomi dan sistem operasional angkutan umum bus. Metode yang digunakan dalam penelitian ini adalah dengan melakukan survei lapangan yaitu penyebaran kuisioner kepada responden serta wawancara langsung kepada pihakpihak yang terkait. Analisis yang dilakukan meliputi analisis karakteristik sosial-ekonomi masyarakat dan analisis perencanaan operasional angkutan. Dari hasil analisis yang telah dilakukan, diperoleh bahwa sebagian besar (71,8 \%) responden menggunakan sepeda motor ke tempat tujuan dengan maksud perjalanan sebagian besar (52,1\%) untuk bekerja, diperoleh 5 rencana trayek angkutan umum bus di Kabupaten Bangka dengan waktu siklus antara 90 s/d 245 menit, dengan headway 10 menit.
\end{abstract}

Kata kunci : Angkutan umum bus, sistem operasional, perencanaan

\section{PENDAHULUAN}

Setiap harinya sebagian besar masyarakat menggunakan kendaraan pribadi menuju kawasan ini, apabila setiap orang menggunakan kendaraan sendiri bisa dibayangkan jumlah kendaraan yang memasuki suatu wilayah setiap harinya. Hal ini tentunya menimbulkan kepadatan lalu lintas pada jam-jam sibuk (peak hour) yaitu pagi hari ketika memulai kegiatan, siang hari ketika waktu istirahat dan sore hari ketika pulang dari kegiatan yang dilakukan.

Maka diperlukan suatu analisis kebutuhan angkutan umum bus untuk Kabupaten Bangka dalam rangka untuk mengetahui karakteristik sosial ekonomi 
masyarakat, besarnya bangkitan perjalanan dan potensi penggunaan angkutan umum bus serta sistem operasional angkutan umum bus yang dapat diterapkan di Kabupaten Bangka, sehingga diharapkan dapat mengatasi persoalan transportasi dan sebagai upaya untuk mengurangi ketergantungan pada kendaraan pribadi.

\section{Tujuan Penelitian}

Secara spesifik tujuan dari penelitian ini adalah:

1. Untuk menentukan karakteristik sosial ekonomi dari masyarakat, besarnya bangkitan perjalanan serta potensi penggunaan angkutan umum bus di Kabupaten Bangka.

2. Untuk menganalisis sistem operasional angkutan umum bus yang dapat diterapkan di Kabupaten Bangka.

\section{LANDASAN TEORI}

\section{Angkutan Umum}

Angkutan dapat dikatakan sebagai sarana untuk memindahkan orang maupun barang dari satu tempat ke tempat lainnya dengan menggunakan kendaraan sedangkan kendaraan umum adalah setiap kendaraan bermotor yang disediakan untuk dipergunakan oleh umum dengan dipungut bayaran (langsung maupun tidak langsung).

\section{Trayek}

Berdasarkan PP No. 41 Tahun 1993 tentang Angkutan Jalan, trayek pelayanan jasa angkutan umum dibagi dalam 4 (empat) kelompok, yaitu:

1. Trayek Antar Kota Antar Propinsi, dengan ciri-ciri pelayanan:

a. Mempunyai jadwal tetap.

b. Pelayanan cepat. c. Dilayani oleh mobil bus umum.

d. Tersedianya terminal tipe A pada awal pemberangkatan, persinggahan dan terminal tujuan.

2. Trayek Antar Kota dalam Propinsi, dengan ciri-ciri pelayanan:

a. Mempunyai jadwal tetap.

b. Pelayanan cepat dan atau lambat.

c. Dilayani oleh mobil bus umum.

d. Tersedianya terminal penumpang sekurang-kurangnya tipe B pada awal pemberangkatan, persinggahan dan terminal tujuan.

3. Trayek Kota, terdiri atas:

a. Trayek Utama, dengan ciri-ciri pelayanan:

1. Mempunyai jadwal tetap.

2. Pelayanan cepat dan atau lambat.

3. Dilayani oleh mobil bus umum.

4. Melayani angkutan antar kawasan utama, antara kawasan utama dan kawasan pendukung dengan ciri melakukan perjalanan ulang-alik secara tetap dengan pengangkutan yang bersifat bus.

5. Jarak pendek.

6. Melalui tempat-tempat yang ditetapkan hanya untuk menaikkan dan menurunkan penumpang.

b. Trayek Cabang, dengan ciri-ciri pelayanan:

1. Mempunyai jadwal tetap.

2. Pelayanan cepat dan atau lambat.

3. Dilayani oleh mobil bus umum.

4. Melayani angkutan antar kawasan pendukung, antara kawasan pendukung dan kawasan permukiman.

5. Jarak pendek. 
c. Trayek Ranting, dengan ciri-ciri

1. Pelayanan lambat.

2. Dilayani oleh mobil bus umum dan/atau mobil penumpang umum.

3. Melayani angkutan dalam kawasan permukiman.

4. Jarak pendek.

5.Melalui tempat-tempat yang telah ditetapkan untuk menaikkan dan menurunkan penumpang.

d. Trayek Langsung, dengan ciri-ciri pelayanan:

1. Mempunyai jadwal tetap.

2. Pelayanan cepat.

3. Dilayani oleh mobil bus umum.

4. Melayani angkutan antar kawasan secara tetap yang bersifat bus dan langsung.

5. Jarak pendek.

Penentuan jenis angkutan berdasarkan klasifikasi trayek dan ukuran kota berdasarkan Pedoman Teknis Penyelenggaraan Angkutan Umum di Wilayah Perkotaan Dalam Trayek Tetap dan Teratur, Direktorat Jendral Perhubungan Darat, Departemen Perhubungan tahun 2002 seperti yang terlihat pada table. Berikut ini adalah tabel penentuan jenis angkutan berdasarkan ukuran kota dan trayek secara umum

\begin{tabular}{|c|c|c|c|c|}
\hline & \multicolumn{4}{|c|}{ Ukuran kota } \\
\hline $\begin{array}{c}\text { Klasif } \\
\text { ikasi }\end{array}$ & $\begin{array}{c}\text { Kota raya } \\
\text { Kota besar }\end{array}$ & $\begin{array}{c}\text { Kota } \\
\text { sedang }\end{array}$ & Kota kecil \\
$\begin{array}{c}\text { Traye } \\
\text { k }\end{array}$ & $\mathbf{1 . 0 0 0 . 0 0 0}$ & $\mathbf{1 . 0 0 0 . 0 0 0}$ & $\mathbf{1 0 0 . 0 0 0 -}$ & $\mathbf{1 0 0 . 0 0 0}$ \\
penduduk & penduduk & $\begin{array}{c}\mathbf{5 0 0 . 0 0 0} \\
\text { penduduk }\end{array}$ & penduduk \\
\hline Utama & $\begin{array}{c}\text { KA, } \\
\text { Bus Besar } \\
\text { (SD/DD) }\end{array}$ & $\begin{array}{c}\text { Bus Besar } \\
\text { pelayanan: }\end{array}$ & $\begin{array}{c}\text { Bus Besar/ } \\
\text { Sedang }\end{array}$ & $\begin{array}{c}\text { Bus } \\
\text { Sedang }\end{array}$ \\
\hline
\end{tabular}

\begin{tabular}{|c|c|c|c|c|}
\hline & \multicolumn{4}{|c|}{ Ukuran kota } \\
\hline $\begin{array}{c}\text { Klasif } \\
\text { ikasi } \\
\text { Traye } \\
\text { k }\end{array}$ & $\begin{array}{c}\text { Kota raya } \\
> \\
1.000 .000 \\
\text { penduduk }\end{array}$ & $\begin{array}{c}\text { Kota besar } \\
500.000- \\
1.000 .000 \\
\text { penduduk }\end{array}$ & \begin{tabular}{|c} 
Kota \\
sedang \\
$100.000-$ \\
500.000 \\
penduduk
\end{tabular} & $\begin{array}{c}\text { Kota kecil } \\
<100.000 \\
\text { penduduk }\end{array}$ \\
\hline $\begin{array}{c}\text { Caban } \\
\mathrm{g}\end{array}$ & $\begin{array}{c}\text { Bus Besar/ } \\
\text { Sedang }\end{array}$ & Bus Sedang & $\begin{array}{c}\text { Bus } \\
\text { Sedang/ } \\
\text { Kecil }\end{array}$ & Bus Kecil \\
\hline $\begin{array}{c}\text { Rantin } \\
\mathrm{g}\end{array}$ & $\begin{array}{c}\text { Bus } \\
\text { Sedang } \\
/ \text { Kecil }\end{array}$ & Bus Kecil & $\begin{array}{c}\text { MPU } \\
\text { (hanya roda } \\
\text { empat) }\end{array}$ & \begin{tabular}{|c} 
MPU \\
(hanya \\
roda \\
empat)
\end{tabular} \\
\hline $\begin{array}{c}\text { Langs } \\
\text { ung }\end{array}$ & Bus Besar & Bus Besar & Bus Sedang & $\begin{array}{c}\text { Bus } \\
\text { Sedang }\end{array}$ \\
\hline
\end{tabular}

\section{Lokasi Perhentian Bus}

Kriteria yang sering digunakan dalam menentukan lokasi perhentian bus terdiri dari empat kelompok, yaitu (Santoso, 1996):

1. Safety, meliputi:

a. Jarak pandang calon penumpang.

b. Keamanan penumpang pada saat turun dan naik bus.

c. Jarak pandang dari kendaraan lain.

d. Gangguan terhadap kendaraan lain pada saat berhenti dan akan berangkat dari perhentian.

e. Mempunyai jarak yang cukup dengan penyebrangan.

2. Traffic, meliputi:

a. Gangguan terhadap lalu lintas lain pada saat bus berhenti.

b. Gangguan terhadap lalu lintas lain pada saat bus masuk dan keluar dari lokasi perhentian.

3. Efisiensi, meliputi:

a. Jumlah orang yang dapat terangkut bus cukup banyak.

b. Dimungkinnya penumpang untuk transfer ke lintasan rute lainnya. 
4. Public Relation, meliputi:

a. Tersedianya informasi yang berkaitan dengan jadwal.

b. Tersedianya tempat sampah yang memadai.

c. Tidak menyebabkan gangguan kebisingan bagi lingkungan sekitar.

\section{Penentuan Jumlah Kendaraan}

Untuk penentuan jumlah kendaraan pada trayek baru, data tentang kebutuhan angkutan didapat dari survei wawancara rumah tangga atau survei sejenis lainnya yang memasukkan pertanyaan tentang preferensi penumpang terhadap pelayanan yang akan diberikan (Departemen Perhubungan, 2002).

Berdasarkan Peraturan Pemerintah Nomor: 41 Tahun 1993 tentang Angkutan Jalan pada pasal 28 ayat (1) menyatakan bahwa "Pembukaan trayek baru dilakukan dengan ketentuan":

a. Adanya permintaan angkutan yang potensial, dengan perkiraan faktor muatan di atas $70 \%$ (tujuh puluh persen), kecuali angkutan perintis.

b. Tersedianya fasilitas terminal yang sesuai.

Berpedoman kepada ketentuan tersebut, apabila mempunyai matriks asal tujuan perjalanan setelah dipisahkan menurut alat angkutnya (angkutan umum), penentuan jumlah kendaraan yang akan dioperasikan untuk trayek baru dapat digunakan pedoman langkah-langkah berikut (Departemen Perhubungan, 2002):

1. Siapkan matriks asal tujuan penumpang angkutan umum.

2. Identifikasi zona-zona potensial (yang pergerakan antar zonanya besar) serta belum dilayani angkutan umum secara langsung $\left(\mathrm{JP}_{1}=\right.$ jumlah penumpang untuk trayek langsung).

3. Identifikasi potensi angkutan pada zonazona lainnya yang akan dilalui trayek tersebut jika pelayanan yang direncanakan bukan trayek langsung tetapi reguler.

4. Jumlahkan permintaan angkutan pada rencana trayek yang akan dilalui tersebut $(\mathrm{JPr}=$ jumlah penumpang untuk trayek reguler).

5. Tentukan jenis dan kapasitas kendaraan yang direncanakan akan melayani trayek tersebut ( $\mathrm{K}=$ kapasitas).

Kapasitas tiap jenis angkutan umum dapat dilihat pada tabel dibawah ini:

\begin{tabular}{|c|c|c|c|l|}
\hline \multirow{2}{*}{ Jenis angkutan } & \multicolumn{3}{|c|}{ Kapasitas kendaraan } & Kapasitas \\
\cline { 2 - 5 } & Duduk & Berdiri & Total & $\begin{array}{l}\text { penpang } \\
\text { perhari/ }\end{array}$ \\
\hline $\begin{array}{c}\text { Mobil penumpang } \\
\text { umum }\end{array}$ & 8 & - & 8 & $250-300$ \\
\hline Bus kecil & 19 & - & 19 & $300-400$ \\
\hline Bus sedang & 20 & 10 & 30 & $500-600$ \\
\hline $\begin{array}{c}\text { Bus besar lantai } \\
\text { tunggal }\end{array}$ & 49 & 30 & 79 & $1000-1200$ \\
\hline $\begin{array}{c}\text { Bus besar lantai } \\
\text { ganda }\end{array}$ & 85 & 35 & 120 & $1500-1800$ \\
\hline
\end{tabular}

Sumber: Departemen Perhubungan, 2002

6. Ukur waktu tempuh dari awal sampai ke akhir trayek beserta waktu berhenti di persinggahan sepanjang lintasan (running time), serta tambahkan waktu singgah (stand time) yang direncanakan di terminal (WT = waktu tempuh).

7. Tentukan jam operasi per hari (JO = lama operasi per hari).

8. Ukur panjang lintasan trayek $(\mathrm{PT}=$ panjang trayek).

9. Taksir rata-rata panjang perjalanan penumpang yang diperkirakan akan menggunakan trayek tersebut $(\mathrm{TL}=$ trip 
length), dengan rumus:

$$
\mathrm{TL}=\sum \mathrm{PT}_{\mathrm{ij}} \mathrm{JP}_{\mathrm{ij}}
$$

$$
\sum \mathrm{JP}_{\mathrm{ij}}
$$

Keterangan:

$\mathrm{TL}=$ Rata-rata panjang perjalanan penumpang (trip length) dalam km

Ptij = Panjang trayek dari zona $\mathrm{i}$ ke zona $\mathrm{j}$ dalam $\mathrm{km}$.

Jtij = Jumlah penumpang dari zona $\mathrm{i}$ ke zona $\mathrm{j}$.

10. Hitung jumlah kendaraan untuk trayek yang direncanakan dengan rumus sebagai berikut:

$$
\mathrm{JK}=\frac{\mathrm{JP}}{\mathrm{K} \times 70 \% \times(\mathrm{JO} / \mathrm{WT})} \times(\mathrm{PT} / \mathrm{TL}) \times \mathrm{C}
$$

Keterangan:

$\mathrm{JK}=$ Jumlah kendaraan yang dibutuhkan.

$\mathrm{JP}=$ Jumlah penumpang.

$\mathrm{K}=$ Kapasitas kendaraan.

$70 \%=$ Faktor muatan .

$\mathrm{JO}=$ Lama operasi per hari.

$\mathrm{WT}=$ Waktu tempuh.

$\mathrm{PT}=$ Panjang trayek.

$\mathrm{TL}=$ Panjang perjalanan .

$\mathrm{C}=$ Faktor koreksi untuk ketepatan data asal tujuan perjalanan $(50 \%)$ adalah judgement dari perencana angkutan.

\section{Perhitungan Waktu Siklus}

Adalah waktu yang dibutuhkan untuk melakukan perjalanan pergi pulang pada suatu trayek, dengan memperhatikan waktu henti di terminal dan waktu hambatan di perjalanan, dalam hal ini terjadi deviasi waktu sebesar 5\% dari waktu perjalanan. Waktu sirkulasi dirumuskan sebagai berikut (Direktorat Jendral Perhubungan Darat, 1996) :
$\mathrm{CTABA}=(\mathrm{TAB}+\mathrm{TBA})+\left(\sigma \mathrm{AB}^{2}+\sigma \mathrm{BA}^{2}\right)+$ $($ TTA +TTB)

Keterangan :

CTABA = Waktu sirkulasi dari A ke B, kembali ke A

$\mathrm{TAB}=$ Waktu perjalanan rata-rata dari $\mathrm{A}$ ke B

TBA = Waktu perjalanan rata-rata dari $\mathrm{B}$ ke A

$\sigma \mathrm{AB}=$ Deviasi waktu perjalanan ratarata dari $\mathrm{A}$ ke $\mathrm{B}$

$\sigma \mathrm{BA}=$ Deviasi waktu perjalanan ratarata dari $\mathrm{B}$ ke $\mathrm{A}$

TTA $=$ Waktu henti kendaraan di terminal A

TTB = Waktu henti kendaraan di terminal B

\section{Perhitungan Frekuensi (f)}

Perhitungan frekuensi merupakan jumlah keberangkatan atau kedatangan kendaraan angkutan kota yang melewati dalam satu trayek selama periode waktu tertentu dan pada satu titik tertentu dan pada satu titik tertentu, (Jason, 1982).

$$
\mathrm{F}=\frac{\mathrm{K}}{60}(\text { kendaraan } / \mathrm{jam})
$$

Keterangan :

$\mathrm{F}=$ Frekuensi (kendaraan/jam)

$\mathrm{K}=$ Jumlah kendaaraan yang beroperasi

(kendaraan)

\section{Perhitungan Headway}

Perhitungan headway merupakan selisih waktu keberangkatan atau kedatangan antara kendaraan angkutan kota dengan kendaraan angkutan kota dibelakangnya dalam satu trayek pada satu titik tertentu. 


\section{Perhitungan Kebutuhan Armada}

Dalam buku Menuju Tertib Lalu Lintas dan Angkutan Jalan Direktorat Jendral Perhubungan Darat (2002), bahwa untuk menentukan kebutuhan jumlah kendaraan angkutan kota yang tetap sesuai dengan kebutuhan sulit dipastikan, yang dapat dilakukan adalah mendekati besarnya kebutuhan. Jumlah kebutuhan angkutan dipengaruhi oleh beberapa faktor yang meliputi :

a. Jarak Rute (L)

Adalah panjang suatu trayek dari titik awal rute sampai titik akhir rute dalam kilometer.

b. Waktu Operasi (To)

Adalah lamanya waktu perjalanan dari titik awal rute sampai akhir rute, dimana waktu operasi ini didapatkan dari hasil survei dilapangan.

c. Faktor Muatan (Lf)

Adalah perbandingan antara jumlah penumpang yang diangkut dalam satu kendaraan dengan jumlah kapasitas tempat duduk yang tersedia dalam kendaraan pada periode waktu tertentu, (Jason C, 1982).

Keterangan $=\frac{\mathrm{Jp}}{\mathrm{C}} \times 100 \%$

Lf $=$ Faktor muatan $(\%)$

$\mathrm{Jp}=$ Jumlah penumpang dalam kendaraan (orang)

$\mathrm{C}=$ Kapasitas kendaraan (orang)

Perhitungan kebutuhan armada adalah jumlah kendaraan yang dibutuhkan untuk melayani satu lintasan tertentu. (Direktorat Jendral Perhubungan Darat, 1996).

$$
\mathrm{Jk}=\frac{\mathrm{CT}}{\mathrm{H} \times \mathrm{fA}}
$$

Keterangan :

$\mathrm{Jk}=$ Jumlah kendaraan yang dibutuhkan

$\mathrm{CT}=$ Waktu sirkulasi (menit)

$\mathrm{H}=$ Headway / waktu antara kendaraan angkutan Kota (menit)

$\mathrm{FA}=$ Faktor ketersediaan kendaraan angkutan kota (\%)

\section{Desain Kuesioner}

Dalam usaha mengumpulkan data, beberapa langkah yang dapat ditempuh (Sudjana, 1996):

a. Mengadakan penelitian langsung ke lapangan atau di laboratorium terhadap obyek penelitian. Hasilnya dicatat untuk kemudian dianalisis.

b. Mengambil atau menggunakan sebagian atau seluruhnya, dari sekumpulan data yang telah dicatat atau dilaporkan oleh badan atau orang lain.

c. Menggunakan angket (kuesioner) adalah cara pengumpulan data dengan menggunakan daftar isian atau daftar pertanyaan yang telah disiapkan dan disusun sedemikian rupa sehingga calon responden hanya tinggal mengisi atau menandai dengan mudah dan cepat.

Dalam pelaksanaannya teknik Stated Preference memiliki tahap-tahap dimana masing - masing tahap tersebut harus memperhatikan hal-hal sebagai berikut (Pearmain, 1990):

1. Tahap identifikasi atribut kunci dan penyusunan paket alternatif. Pilihan semua atribut esensial harus dipergunakan dan paket - paket alternatif pilihan yang ditawarkan harus masuk akal dan realistik.

2. Tahap penyusunan formulir survei. Bentuk penyajian formulir survei dan tata cara memberikan respon pertanyaan 
survei harus mudah dimengerti dan berada dalam konteks pengalaman dan kendalakendala yang sesuai dengan situasi responden yang diteliti.

3. Tahap penyusunan cara pengambilan data. Dalam pengambilan data perlu dibuat strategi sampling yang akan dikerjakan untuk menjamin diperolehnya data yang representative.

4. Tahap pelaksanaan survei Stated Preference. Dalam tahap pelaksanaan survei ini diperlukan keterangan pendahuluan yang menerangkan maksud dan tujuan survei, alternatif situasi perjalanan yang dibuat dan cara memberikan jawabannya.

5. Tahap analisis data Stated Preference. Untuk menganalisis data stated preference diperlukan model analisis yang sesuai dengan tujuan analisis dan ketersediaaan data yang ada.

\section{Desain Sampel}

Populasi (universe) totalitas dari semua objek atau individu yang memiliki karakteristik tertentu, jelas dan lengkap yang akan diteliti, (Iqbal, 2002). Ditinjau dari banyaknya anggota populasi, maka populasi dapat dibagi menjadi populasi tak hingga adalah populasi yang beranggotakan tak hingga atau berukuran tak hingga dan populasi terhingga dimana didalamnya terdapat terhingga banyak anggota, (Sudjana, 1996).

Salah satu metode yang digunakan untuk menentukan jumlah sampel adalah menggunakan rumus Slovin (Sevilla et. al., 1960:182), sebagai berikut:

$$
n=\frac{N}{1+N e^{2}}
$$

Keterangan :

$n \quad$ : jumlah sampel

$\mathrm{N} \quad$ : jumlah populasi

e : batas toleransi kesalahan (error tolerance)

Untuk menggunakan rumus ini, pertama ditentukan berapa batas toleransi kesalahan. Batas toleransi kesalahan ini dinyatakan dengan persentase. Semakin kecil toleransi kesalahan, semakin akurat sampel menggambarkan populasi. Misalnya, penelitian dengan batas kesalahan $5 \%$ berarti memiliki tingkat akurasi 95\%. Penelitian dengan batas kesalahan $2 \%$ memiliki tingkat akurasi $98 \%$. Dengan jumlah populasi yang sama, semakin kecil toleransi kesalahan, semakin besar jumlah sampel yang dibutuhkan.

\section{METODE PENELITIAN}

\section{Lokasi Penelitian}

Dalam penelitian ini dipilih kawasan Kabupaten Bangka sebagai lokasi penelitian. Idealnya seluruh kabupaten di Bangka Belitung harus dianalisis secara menyeluruh guna mendapatkan jaraingan transportasi yang terintegrasi. Tetapi karena penulis memiliki keterbatasan biaya, waktu dan tenaga maka diambil satu daerah Kabupaten sebagai sampel yang diprediksi mempunyai bangkitan perjalanan yang relatif besar.

\section{Metode Pengumpulan Data}

Data yang dibutuhkan dalam penelitian ini terdiri dari dua kelompok, yaitu data primer dan data sekunder. 
Data Primer

Dalam melakukan penelitian ini, pengumpulan data primer dilakukan dengan state preference survey yang dilakukan dengan cara wawancara merupakan survei untuk mengumpulkan data perjalanan yang dilakukan setiap anggota keluarga.

Kuisioner yang digunakan berisikan data karakteristik ekonomi dan data transportasi. Didalam pengambilan data primer, data yang diambil yaitu data keluarga, data perjalanan, biaya perjalanan/bulan, dan pola perjalanan. Data keluarga yang akan ditanyakan disetiap responden yang di survey, misalnya status dalam keluarga, umur, dan pekerjaannya. Data Perjalanan diambil berdasarkan kegiatan/rutinitas responden sehari-hari, dan pola perjalanan dapat diakumulasikan dengan frekuensi perjalanan per minggu.

\section{Data Sekunder}

Pengumpulan data sekunder adalah pengumpulan data dan informasi dari literatur dan studi-studi terdahulu.

\section{Bagan Alir (Flowchart) Penelitian}

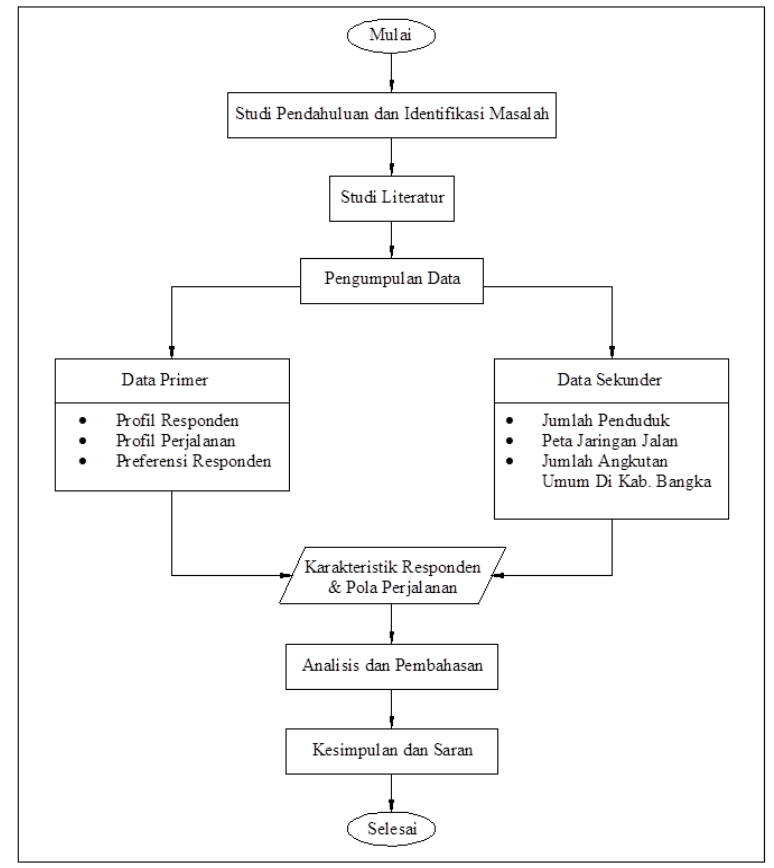

\section{Pengolahan Data}

Pengolahan data dengan jumlah sampel responden yaitu sebanyak 397 rumah tangga yang tersebar di 5 kecamatan. Setelah data terkumpul dari survei wawancara rumah tangga (Origin-Destination survey), data-data tersebut kemudian diolah dengan tahapantahapan sebagai berikut ini.

\section{Coding}

Coding adalah proses pemberian kode pada kuisioner (form terlampir). Kodekode tersebut diberikan dalam angka untuk keseragaman dan kemudahan dalam pengolahan data. Adapun parameterparameter yang diberi kode adalah sebagai berikut ini.

a. Zona tiap-tiap kecamatan

b. Data sosial keluarga dan perjalanan langsung mengikuti pola penomoran yang ada di form survei State Preference (form terlampir).

\section{Editing}

Editing yaitu data-data yang tidak lengkap atau tidak wajar disaring supaya tidak masuk dalam pengolahan data.

\section{Entering}

Data-data tersebut kemudian ditabulasikan sesuai dengan urutan kode masing-masing.

\section{Sorting Data}

Setelah data ditabulasikan, data tersebut disorting dengan menggunakan Microsoft Excel sesuai dengan kebutuhan pemodelan.

\section{HASIL DAN PEMBAHASAN \\ Perencanaan Rute Layanan}

Perencanaan rute layanan angkutan umum bus didasarkan atas lokasi kebutuhan demand, berdasarkan hasil survey yang telah dilakukan pada 397 responden. Dari hasil survey stated preference diperole data responden yang 
bersedia beralihh menggunakan angkutan umum bus sebesar 296 orang atau 74,6\% dari 397 responden.

Selanjutnya data dari hasil survey terhadap responden tersebut dipetakan pada ruas jalan pada wilayah studi. Pada studi ini pemberian kode di setiap trayek menggunakan simbol T-1, T-2, T-3, T-4, dan T-5. Pemberian urutan dan nama trayek bertujuan untuk memudahkan pengguna angkutan dalam memilih trayek yang akan dilaluinya. Berikut hasil rancangan rute dan pola pelayanan yang diperoleh untuk melayani kawasan Kabupaten Bangka sebanyak 5 jaringan trayek seperti pada gambar dibawah ini

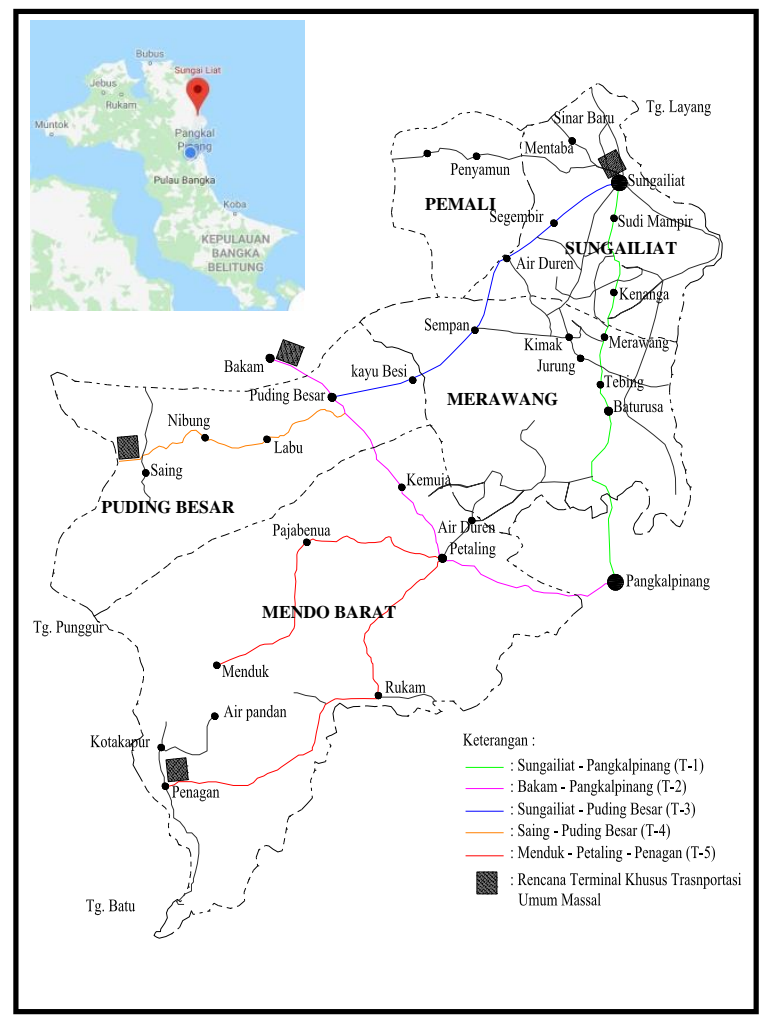

Gambar 1. Peta Lokasi Studi

\section{Potensi Penggunaan Angkutan Umum Bus}

Potensi penggunaan angkutan umum bus diperoleh berdasarkan hasil survey stated preference pada 397 sampel. Dari hasil survey tersebut kemudian diperoleh jumlah responden yang berminat menggunakan angkutan umum bus adalah sebesar 296 orang atau sebesar $74,6 \%$ dari jumlah sampel yang di ambil sebesar 397 sampel. Dari hasil survey tersebut, maka dapat di estimasi jumlah penumpang yang akan dilayani angkutan umum bus pada kawasan Kabupaten Bangka adalah sebesar $74,6 \%$ x 216.724 orang (jumlah seluruh populasi) $=161.676$ orang.

Dari matrik asal-tujuan dapat dijumlahkan persentase pengguna angkutan umum bus yang melewati trayek-trayek yang telah direncanakan yaitu $51,6 \%$ untuk trayek Sungailiat - Pangkalpinang (T-1), 19,9\% untuk trayek Bakam - Pangkalpinang (T-2), $8,3 \%$ untuk trayek Sungailiat - Puding Besar (T3), 4,8 \% untuk trayek Saing - Puding Besar (T-4) dan 15,4 \% untuk trayek Menduk - Petaling - Penagan (T-5). Persentase tersebut didapat dari pengolahan matrik asaltujuan yang telah di komulasikan berdasarkan tempat dan tujuan penumpang, berikut ini adalah grafik persentase pengguna trayek.

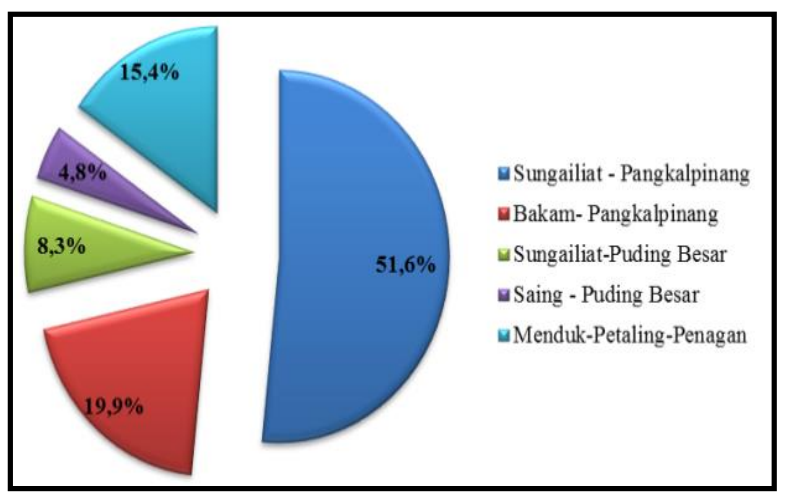

Gambar 2. Grafik Persentase Pengguna Trayek

\section{Karakteristik sosial ekonomi penduduk}

Besarnya bangkitan perjalanan serta potensi penggunaan angkutan umum bus terbagi berdasarkan sebagai berikut : 
a. Kepemilikan kendaraan

Sebanyak 18,4 \% responden memiliki mobil, $71,8 \%$ rata- rata responden memiliki motor, $1,3 \%$ memiliki sepeda tak bermotor dan $8,6 \%$ responden menggunakan kendaraan lainnya.

b. Maksud dari perjalanan

Maksud perjalanan responden paling banyak adalah bekerja dengan persentase $52,1 \%$, kemudian $12,6 \%$ urusan keluarga/rekreasi, $15,1 \%$ sekolah, dan 20,2\% lainnya.

c. Biaya transportasi

Biaya transportasi keluarga per bulan yang memiliki persentase paling tinggi adalah 80,6\% yaitu kurang dari Rp.500.000 dan persentase pengeluaran biaya transportasi keluarga per bulan yang paling rendah adalah 1,8\% yaitu antara Rp.3.000.000 4.000.000.

d. Prosentase pendapatan responden

Prosentase pendapatan responden paling tinggi adalah $35,3 \%$ responden yang memiliki pendapatan antara Rp. 1.500.000 - 2.500.000, kemudian 25,9\% responden memiliki pendapatan antara Rp. 5.000.000 - 7.500.000, 19,6\% responden memiliki pendapatan lebih dari Rp. 20.000.000, $6,5 \%$ memiliki pendapatan kurang dari Rp.500.000 dan yang terakhir 0,8\% responden memiliki pendapatan antara Rp. 2.500.000 - 5.000.000.

e. Minat terhadap pemakaian angkutan umum bus

Dari 397 sampel yang diambil, sebanyak $74,6 \%$ (296 orang) responden berminat untuk beralih dari kendaraan yang digunakan saat ini menggunakan angkutan umum bus dan 25,4 \% (101 orang) responden tidak bersedia beralih menggunakan angkutan umum bus.

f. Asal responden

Persebaran alamat responden yang memiliki prosentase paling besar adalah di Sungailiat 43,39\%, kemudian Mendo Barat sebesar 21,75\%, Pemali 13,37\%, Merawang sebesar 13,30\% dan Puding Besar sebesar 8,19\%.

g. Fasilitas yang diinginkan

Sebagian besar mengharapkan kendaraan dilengkapi fasilitas AC, TV, dan tidak berdesakan.

\section{Sistem Operasional Pelayanan}

$\underline{\text { Kebutuhan Pemberhentian atau Halte }}$

Pada pelayanan angkutan umum bus ini dilakukan dilakukan penjemputan pada tempat pemeberhentian khusus yang telah telah ditentukan.

Penentuan jumlah halte pada layanan ini adalah berdasarkan hasil survey lapangan pada lintasan yang telah disusun sehingga diperoleh titik lokasi halte pada ruas jalan atau perpotongan antar trayek dan selain itu juga memperhatikan besarnya estimasi jumlah penumpang pada masing - masing lintasan.

Pada tahap awal pelaksanaan dibutuhkan halte sebanyak 54 unit dapat dilihat pada tabel berikut ini.

Tabel 1. Jumlah Kebutuhan Halte

\begin{tabular}{|l|l|l|l|}
\hline No. & Kode & Nama trayek & $\begin{array}{l}\text { Jumlah } \\
\text { kebutuhan } \\
\text { halte (unit) }\end{array}$ \\
\hline 1 & T-1 & $\begin{array}{l}\text { Sungailiat } \\
\text { Pangkalpinang }\end{array}$ & 11 \\
\hline 2 & T-2 & Bakam - Pangkalpinang & 12 \\
\hline 3 & T-3 & Saing - Puding Besar & 8 \\
\hline
\end{tabular}




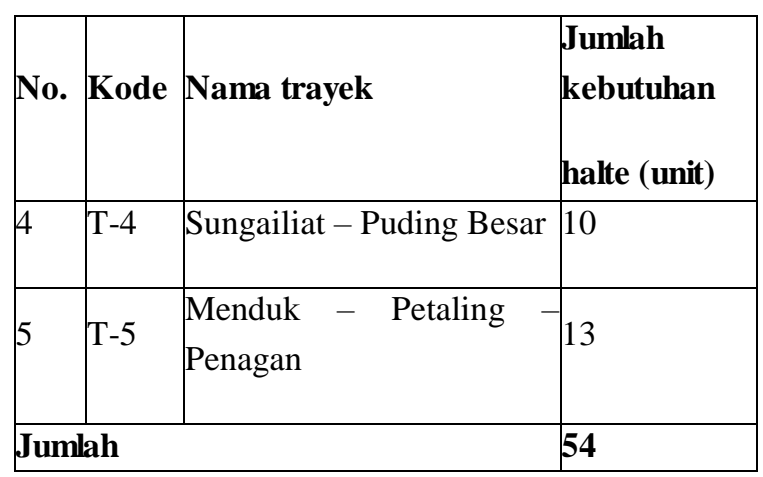

Berikut titik lokasi halte yang ditentukan berdasarkan demand dan eksisting tata guna lahan yang ada.

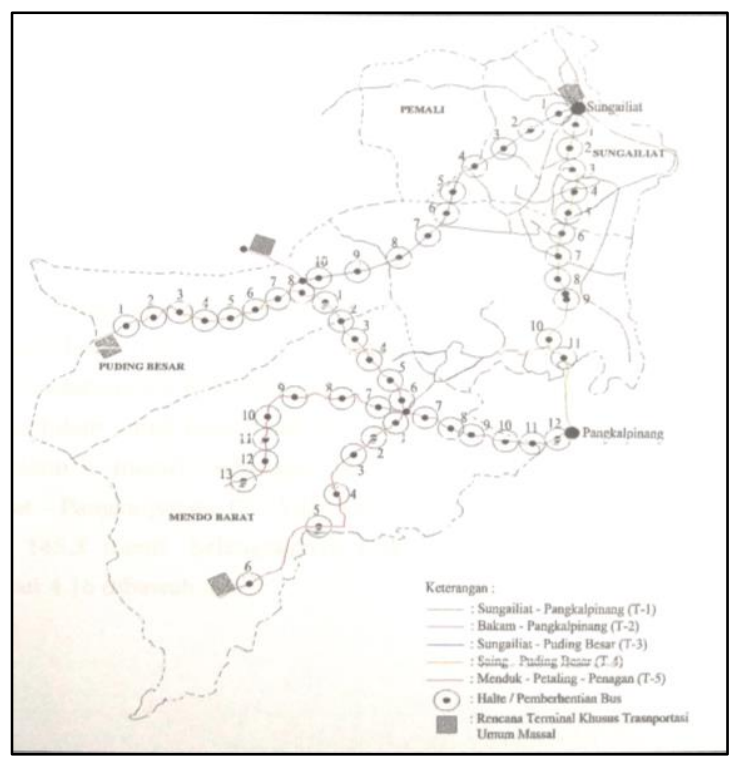

Gambar 3. Titik Lokasi Halte

\section{Perhitungan Waktu Siklus}

Berikut contoh perhitungan waktu siklus pada trayek T-1 lintasan Sungailiat Pangkalpinang :

Deviasi kendaraan untuk Angkutan Umum bus dihitung berdasarkan waktu yang diperlukan untuk menaikkan dan menurunkan penumpang di setiap halte (diperkirakan 1 menit). Sehingga didapat total waktu sirkulasi pada trayek Sungailiat - Pangkalpinang (T1) dan kembali ke Sungailiat (CTABA) = $134,4+11=145,5$ menit. Selengkapnya waktu sirkulasi pada trayek dapat dilihat pada grafik berikut ini.

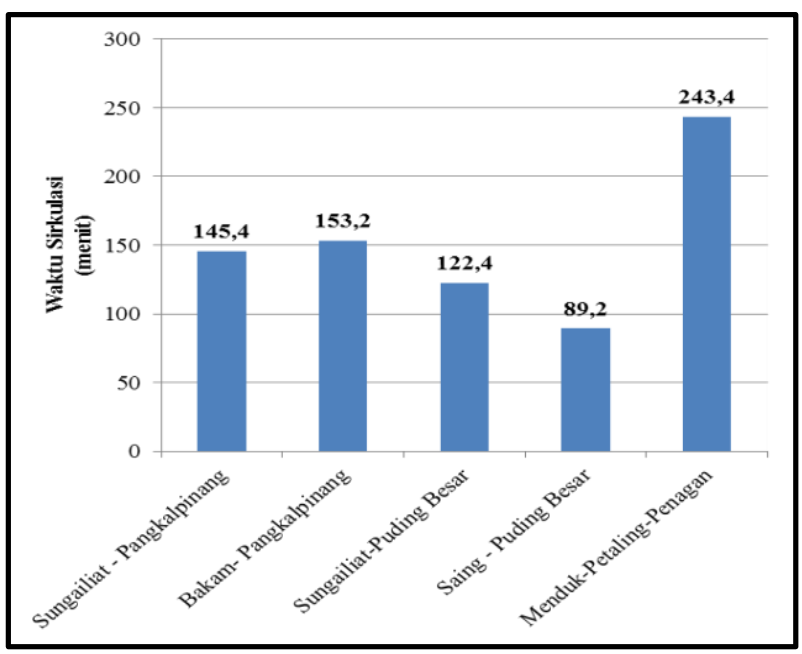

Gambar 4. Grafik waktu sirkulasi tiap trayek

\section{Headway (h)}

Perhitungan headway merupakan selisih waktu keberangkatan antara dua pelayanan kendaraan angkutan pada suatu titik tertentu, atau selisih waktu kedatangan antara satu kendaraan dengan kendaraan berikutnya, biasanya pada bus stop (dalam menit). Dalam penelitian ini rata-rata waktu keberangkatan 10 menit untuk semua trayek berdasarkan pendapat responden dari hasil survey.

\section{Kebutuhan Armada}

Perhitungan kebutuhan armada merupakan jumlah kendaraan yang dibutuhkan untuk melayani satu lintasan tertentu, misalnya pada trayek Pangkalpinang - Sungailiat dibutuhkan kendaraan sejumlah :

JK (Jumlah Kendaraan $)=\frac{C T}{H \times f A}=\frac{145,4 \text { menit }}{10 \text { menit } \times 100 \%}=15$ Kendaraan

Perhitungan kebutuhan kendaraan untuk trayek lainnya dapat dilihat pada Tabel berikut. 
Tabel 2. Kebutuhan Kendaraan Untuk Trayek

\begin{tabular}{|l|l|l|l|l|}
\hline $\begin{array}{l}\text { N } \\
\text { o }\end{array}$ & $\begin{array}{l}\text { Kod } \\
\text { e }\end{array}$ & $\begin{array}{l}\text { Nama } \\
\text { Trayek }\end{array}$ & $\begin{array}{l}\text { Waktu } \\
\text { Sirkulasi } \\
\text { CT }\end{array}$ & $\begin{array}{l}\text { Kebutuh } \\
\text { an } \\
\text { Kendara } \\
\text { an Per } \\
\text { Shift }\end{array}$ \\
\hline 1 & T-1 & $\begin{array}{l}\text { Sungailiat - } \\
\text { Pangkalpinan } \\
\text { g }\end{array}$ & 145,4 & 15 \\
\hline 2 & T-2 & $\begin{array}{l}\text { Bakam- } \\
\text { Pangkalpinan } \\
\text { g }\end{array}$ & 153,2 & 15 \\
\hline 3 & T-3 & $\begin{array}{l}\text { Sungailiat- } \\
\text { Puding Besar }\end{array}$ & 122,4 & 12 \\
\hline 4 & T-4 & $\begin{array}{l}\text { Saing } \\
\text { Puding Besar }\end{array}$ & 89,2 & 9 \\
\hline 5 & T-5 & $\begin{array}{l}\text { Menduk- } \\
\text { Petaling- } \\
\text { Penagan }\end{array}$ & 243,4 & 24 \\
\hline Jumlah & \multicolumn{2}{|l}{} \\
\hline
\end{tabular}

Berdasarkan hasil analisis dari 5 rancangan trayek angkutan umum bus, secara keseluruhan layanan membutuhkan 75 kendaraan untuk beroperasi dan 1 unit cadangan untuk semua trayek sehingga totalnya 76 kendaraan.

\section{Waktu Pelayanan (Ts)}

Waktu pelayanan angkutan umum bus didefinisikan sebagai total waktu pelayanan angkutan umum bus dalam satu hari. Dalam penelitian ini, waktu pelayanan didesain selama 7 jam/hari yang terbagi dalam 3 shift. Shift I beroperasi mulai pukul $05.00 \mathrm{~s} / \mathrm{d}$ 08.00 dilanjutkan dengan shift II yang beroperasi mulai pukul $11.00 \mathrm{~s} / \mathrm{d} 13.00$ dan shift III beroperasi mulai $15.00 \mathrm{~s} / \mathrm{d}$ 17.00. Dengan kata lain, waktu pelayanan efektif kendaraan dalam sehari adalah 7 jam.

\section{KESIMPULAN DAN SARAN \\ Kesimpulan}

Berdasarkan analisis data dan pembahasan yang dilakukan pada bab-bab sebelumnya, maka dapat diperoleh beberapa kesimpulan sebagai berikut :

1. Karakteristik sosial ekonomi penduduk, besarnya bangkitan perjalanan serta potensi penggunaan angkutan umum bus pada wilayah Kabupaten Bangka adalah sebagai berikut :

a. Sebanyak $18,4 \%$ responden memiliki mobil, $71,8 \%$ rata- rata responden memiliki motor, $1,3 \%$ memiliki sepeda tak bermotor dan $8,6 \%$ responden menggunakan kendaraan lainnya.

b. Maksud perjalanan responden paling banyak adalah bekerja dengan persentase $52,1 \%$, kemudian $12,6 \%$ urusan keluarga/rekreasi, 15,1\% sekolah, dan $20,2 \%$ lainnya.

c. Biaya transportasi keluarga per bulan yang memiliki persentase paling tinggi adalah 80,6\% yaitu kurang dari Rp.500.000 dan persentase pengeluaran biaya transportasi keluarga per bulan yang paling rendah adalah 1,8\% yaitu antara Rp.3.000.000 4.000.000.

d. Prosentase pendapatan responden paling tinggi adalah $35,3 \%$ responden yang memiliki pendapatan antara Rp. 1.500.000 - 2.500.000, kemudian 25,9\% responden memiliki pendapatan antara Rp. 5.000.000 - 7.500.000, $19,6 \%$ responden memiliki pendapatan lebih dari Rp. 20.000.000, $6,5 \%$ memiliki pendapatan kurang dari Rp.500.000 dan yang terakhir 0,8\% responden memiliki pendapatan antara Rp. 2.500.000 - 5.000.000.

e. Dari 397 sampel yang diambil, sebanyak 
$74,6 \%$ (296 orang) responden berminat untuk beralih dari kendaraan yang digunakan saat ini menggunakan angkutan umum bus dan 25,4 \% (101 orang) responden tidak bersedia beralih menggunakan angkutan umum bus.

f.Persebaran alamat responden yang memiliki prosentase paling besar adalah di Sungailiat 43,39\%, kemudian Mendo Barat sebesar 21,75\%, Pemali 13,37\%, Merawang sebesar $13,30 \%$ dan Puding Besar sebesar 8,19\%.

g. Berdasarkan fasilitas yang diinginkan yaitu sebagian besar mengharapkan kendaraan dilengkapi fasilitas AC, TV, dan tidak berdesakan.

Besarnya bangkitan perjalanan yang memiliki persentase paling besar adalah Sungailiat yaitu 41,56\%, kemudian diikuti oleh Mendo Barat dengan persentase 21,66\%, Merawang 35\%, Pemali 13,35\%, dan Puding Besar sebesar 10,08\%.

2. Sistem operasional angkutan umum bus yang dapat diterapkan pada wilayah Kabupaten Bangka adalah sebagai berikut:

a. Dari 5 trayek angkutan umum bus yaitu Trayek T-1 lintasan Sungailiat Pangkalpinang, Trayek T-2 lintasan Bakam - Pangkalpinang, Trayek T-3 lintasan Sungailiat - Puding Besar, Trayek T-4 lintasan Saing - Puding Besar, dan T-5 Lintasan MendukPetaling-Penagan. Berdasarkan potensi jumlah penumpang pada masing-masing trayek ditetapkan headway-nya 10 menit, waktu siklusnya antara 90 s/d 245 menit. b. Kebutuhan kendaraan setiap shift yaitu
15 buah kendaraan pada trayek Sungailiat - Pangkalpinang (T-1), 15 buah kendaraan pada trayek Bakam Pangkalpinang (T-2), 12 buah kendaraan pada trayek Sungailiat - Puding Besar (T-3), 9 buah kendaraan pada trayek Saing - Puding Besar (T-4), dan 24 buah Kendaraan pada trayek MendukPetaling-Penagan (T-5).

c. Pelayanan angkutan umum bus ini berlaku untuk umum. Waktu pelayanan didesain selama 17 jam/hari yang terbagi dalam 3 shift. Shift I beroperasi mulai pukul 05.00 s/d 08.00 dilanjutkan dengan shift II yang beroperasi mulai pukul 11.00 s/d 13.00 dan shift III beroperasi mulai $15.00 \mathrm{~s} / \mathrm{d} 17.00 \mathrm{WIB}$.

\section{Saran}

Berdasarkan simpulan yang diperoleh dari penelitian ini, terdapat beberapa saran yang perlu diusulkan demi kesempurnaan penelitian ini adalah :

a. Berdasarkan hasil penelitian terdapat $25,4 \%$ responden yang tidak bersedia menggunakan angkutan umum bus, sehingga untuk memaksimalkan demand yang akan menggunakan angkutan, diperlukan campur tangan pemerintah untuk menetapkan kebijakan-kebijakan serta melakukan sosialisasi tentang angkutan umum bus.

b. Untuk masyarakat yang bekerja pada Pemerintahan Daerah atau perusahaan perusahaan lainnya maka disarankan untuk menggunakan transportasi khusus karyawan.

\section{DAFTAR PUSTAKA}

Departemen Perhubungan. 2002. Pedoman 
Teknis Penyelenggaraan Angkutan

Penumpang Umum di Wilayah

Perkotaan dalam Trayek dan Teratur,

Jakarta: Direktorat Jenderal

Perhubungan Darat.

Departemen Perhubungan. 2003.

Keputusan Mentri Perhubungan

Nomor KM. 35 Tahun 2003 tentang

Penyelenggaraan angkutan Orang di

Jalan dengan Kendaraan Umum.

Jakarta: Direktorat Jenderal

Perhubungan Darat.

Departemen Perhubungan. 1993.

Peraturan Pemerintah No.41 Tahun

1993 tentang Angkutan Jalan. Jakarta:

Direktorat Jenderal Perhubungan

Darat.

Departemen Perhubungan. 1996.

Penentuan Jumlah Armada dan

Penjadwalan. Jakarta: Badan

Pendidikan dan Latihan Perhubungan

Pusat Pendidikan dan Latihan

Perhubungan Darat.

Ekasari, Mutia Astri. 2016. Evaluasi Rute dan Halte Bus di Kota Bandung. Bandung: Program Studi Perencanaan Wilayah dan Kota Fakultas Teknik Unisba.

Eldon, Mokhamad. 2016. Analisis Kualitas

Pelayanan Transportasi Bus Sekolah

Dinas Perhubungan, Komunikasi dan Informatika Kabupaten Tulunagung. Tulungaguang: Fakultas Ekonomi Universitas Tulungagung .
Firmansya Al Rasyid, Bagus Rio. 2015. Kualitas Pelayanan Transportasi Publik (Studi Deskriptif tentang Kualitas Pelayanan Jasa Angkutan Umum Perum Damri Unit Angkutan Bus Khusus Gresik-Bandara Juanda. Surabaya: FISIP Unair .

FSTPT - ITB. 1999. Studi Evaluasi Tarif Angkutan Umum dan Analisis Ability to Pay (ATP) dan Willingness to Pay (WTP) di DKI Jakarta. Bandung : Kelompok Bidang Keahlian Rekayasa Transportasi Jurusan Teknik Sipil.

Igbal, H. M. 2002. Pokok - Pokok Materi Statistik 2. Jakarta: PT. Bumi Aksara. LPM - ITB. 1997. Studi Kelayakan Proyek Transportasi. Bandung: Lembaga Pengabdian Masyarakat ITB bekerjasama dengan Kelompok Bidang Keahlian Rekayasa Transportasi Jurusan Teknik Sipil ITB.

Junior Natal Pangodian, Natal. 2016. Analisis Kebutuhan Angkutan Umum Penumpang Kota Manado (Studi Kasus : Paal Dua-Politeknik). Manado: Jurusan Teknik Sipil Fakultas Teknik Universitas Sam Ratulangi.

Ortuzar, J.D. 1994. Modeling Transport. England: John Wiley \& Sons, Chichester.

Parikesit, D. 1993. Kemungkinan Penggunaan Stated Preferrence dalam Perencanaan Angkutan Umum. Yogyakarta: Jurusan Teknik Sipil 
Fakultas Teknik UGM.

Pearmain, D. 1990. Stated Preference Technigues. Belanda: A Guide to Practice. Hague Consultancy Group, Den Haag.

Santoso, I. 1996. Perencanaan Prasarana Angkutan Umum. Bandung: Pusat Transportasi dan Komunikasi. Institut Teknologi Bandung.

Sudjana, 1996. Metode Statistika.
Bandung: Penerbit Tarsitu Bandung.

Tamin, O.Z. 2000. Perencanaan dan Pemodelan Transportasi. Bandung: Penerbit ITB.

Warpani S.P. 2002. Pengelolaan Lalu Lintas dan Angkutan Jalan. Bandung: Penerbit ITB.

Widayanti, Ari, dkk. 2014. Permasalahan dan Pengembangan Angkutan Umum di Kota Surabaya. Surabaya: Jurusan Teknik Sipil Fakultas Teknik Universitas Negeri Surabaya. 